\title{
The Bacas and the Priests: How Old Adversaries Came Together to Revive and Reinterpret Tradition
}

\section{PAWEL SENDYKA}

Institute of Ethnology and Cultural Anthropology Jagiellonian University, Kraków, Poland

pawel.sendyka@uj.edu.pl

\begin{abstract}
In the Polish pastoralist tradition there have always been two seminal community events which bracketed the winter season. There was the autumn event of "Redyk Jesienny" when the sheep brought back from the summer alpine pastures were given back to their owners and there was also a spring "Redyk" also called "Mieszanie Owiec" which literally means the Mixing of Sheep. Historically, it was an important event in which the head shepherd, or the baca had to use his magical knowledge to ensure that the big herd made up of sheep from the individual owners would keep together as one and produce enough milk to make this summer venture profitable. To do that he used magic spells and performed rituals learned from his predecessors. The bacas' magical knowledge was frequently in opposition to the powers of the priests who viewed them with suspicion. Today, this spring event of "Mieszanie Owiec" is much changed. It is no longer a private affair of the baca and the sheep owners. Frequently, it is a public event, a tourist attraction, with the priests often taking centre stage. There is even a new, "invented" tradition of region wide "Mieszanie" at the sanctuary of Ludźmierz. There, a small herd of around 200 sheep is symbolically used to bless all the herds going up the mountain pastures for the season. The paper examines how these traditions changed from old ethnographic descriptions and how they are evolving in a modern economic and social reality.
\end{abstract}

KEY WORDS: baca, priest, tradition, revival, reinvention, Mixing of the Sheep, Christianity, pastoralism, Poland, Gorce Mountains 


\section{Introduction}

In the Polish pastoralist tradition there have always been two seminal community events which bracketed the winter season. There was the autumn event of "Redyk Jesienny" when the sheep brought back from the summer alpine pastures were given back to their owners. There was also a spring "Redyk" also called "Mieszanie Owiec" which literally means Mixing of Sheep.

At the beginning of May in 2015, the pastoral season in Ochotnica Górna was starting with a festive celebration of Mieszanie Owiec. It began with a mass in a small chapel in the hamlet of Jamne, next to a creek that goes deep into the Gorce Mountains (they lie just north of the Tatras, belonging to the broadly defined Podhale). There was a band, playing the local Highland music, dressed in their traditional, festive clothes that are so iconic in Polish popular culture. The priest, baca Jasiek, the sheep owners and villagers all walked accompanied by this band and their music from the chapel to the field across the road where, on fresh spring grass, a koszar - the wooden enclosure with the sheep - awaited. The priest and the baca walked together into the enclosure, took their hats off and the priest thanked God for the mountains and the woods and the pastures on which these sheep can graze, until they are full and asked them to be blessed so that they may be kept away from danger and sickness. He then dipped a fir branch in a wooden bucket which baca Jasiek was holding and sprayed the holy water on the herd. Baca Jasiek then took the fir branch from him and kept spraying the sheep with holy water while moving clockwise around the enclosure. He did that three times circling with the sheep around a freshly cut fir tree stuck in the middle, as is the tradition. He then took burning incense made of herbs from the priest and circled with it three times letting the smoke waft through the herd.

Everything was very traditional, except perhaps for the fact that it was not that traditional at all. Baca Jasiek explained what he did at this celebration this way:

"I was the one to introduce the priest into it, because I don't feel myself a strong enough magician so that I would be able to do magic myself and so on... or to pray in a way that there would be strength in it. And such strength, in our times... I believe in God... is with the priest who has faith, and he is there to guide these people and set out certain things."

Historically, Mieszanie Owiec was an important event during which the head shepherd, or the baca had to use his magical knowledge to ensure that the big herd made up of sheep from the individual owners would keep together as one and produce enough milk to make 

Tradition

their summer venture profitable. To do that he used magic spells and performed rituals learned from his predecessors.

The explanation why this new alliance between the bacas and the priests is a reversal of age-old animosity, requires a brief look into their common history within the history of pastoralism in Poland. The suspicions the priests have always harboured against the bacas could be seen as justifiable if one considers the tradition from which the bacas came from.

\section{Origin of the bacas}

The sheep and the practice of transhumant pastoralism were brought to Poland by Wallachian shepherds towards the end of the Middle Ages. Thought to have first originated in the Balkans, the exact reasons for the mass migrations of the era are a matter of conjecture, with Turkish expansion of the 14th century (JAWOR 1997:53), power struggles between nobles in Wallachia and Moldavia (JAWOR 2014:26) and a need for new pastures as a result of the population growth (DOBROWOLSKI 1970:90), all being pointed to as possible causes. There are indications that this influx of people was at least in part sponsored and supported by the Polish state that sought, at the time, to make the mountains both productive and strengthened militarily (JAWOR 2000:31).

The mountains and other difficult terrains were places where the agricultural settlements have failed because of the much shorter vegetation periods than in the lowlands and the soil of much poorer quality. After the initial tax free periods, these settlements were unable to support themselves and to pay their obligations (JAWOR 2014:26). The Polish introduced state a novel legislation to cater to the new Wallachian arrivals, who re-settled under this new law many of the failed agricultural villages. The co-called "German Law" (or lus Teutonicum in Latin), which operated for the agricultural settlers from Germany that settled in Poland in the 12th century, stipulated that the rights and responsibilities of the settlers and the landowners; the settlers commonly paying rent in grain and/or money, as well as performing corvee labour for the land owners. The new "Wallachian Law" (or lus Valachicum in Latin) was different: corvee labour was very limited or completely abolished and the rent could be paid in pastoral products: sheep, fleece, wool and cheese. The settlers had more personal freedom, being allowed to leave the settlement without the landowner's permission. The Wallachians brought with them the sheep and the pastoral know-how and made the mountains economically profitable for 

Tradition

the local landowners and the Polish state. They were also skilled artisans in carpentry, leather-work and blacksmithing. It was their ability to mix the proportions of pastoralism, small-time agriculture, and craftsmanship in a way best suited to local conditions that made them successful over large areas (JAWOR 2014:27). In time, as the Wallachians dissolved in the local population, the meaning of the word Wallachian (or Vlach) was changing over time (and space) to include, amongst other meanings, anyone who would be living in the settlements under the new law. Grzegorz Jawor (2000:27-28) argues that while the structure of the lus Valachicum came from the lus Teutonicum, its substance was foreign in origin; that it was not so much of an adjustment of the law, rather a whole new paradigm. For people who would be signing up for such a settlement, it would be a break off with the past experience as agriculturalists and an embarkment on a whole new way of doing animal husbandry, a change in lifestyle that went with an acceptance of a new set of values, often contradictory to those lived by so far.

Pastoralism became the way to make a living in the mountains, for centuries. Yet, the initial encounters were not all auspicious. In 1406 the Wallachians burned down the city of Stary Sącz, committing many acts of pillage and murder. The chronicler relaying these events attributes to them such characteristics as violence and barbaric manners, he also calls them schismatics. This is because the Wallachians were not only Orthodox, but their "Wallachian faith" differed from Orthodoxy by a special worship of Saint Dymitr, as evidenced by their oaths (recorded in court proceedings) which ended by the phrase "so help me God and Saint Dymitr" (Ita me Deus adiuvet et s. Dmytr in Latin) (JAWOR 2000:19, 24). The Wallachians also gained a bad reputation as horse and sheep thieves. The old court records show that they were also accused of a variety of other transgressions: producing and distributing fake coins, beatings and other types of bodily harm, rape, arson and acting in cahoots with the highwaymen. This dubious reputation coupled with a different way of life and a different faith was causing a great mistrust of the locals. There would be panic and protests at a mere suggestion of a possible Wallachian settlement. In 1516 a local castellan had to assuage the fears of the Church officials in Kraków that the planned settlement in the woods behind Myślenice is to be settled with Christians and not Wallachians and it is to suppress the attacks by the latter (JAWOR 2000:164). This bad reputation persisted over the years and the bacas come from that Wallachian legacy of real and perceived violence, lawlessness and schismatism. There were also other reasons, why the priests would consider the bacas adversaries. 


\section{The bacas' magical powers}

As was mentioned before, baca is a head shepherd, a person on whose reputation the yearly communal sheep grazing has depended on for as long as the sheep have been in Polish mountains. He would be the one to collect the sheep from individual owners and take them up to the mountains for the season. All the stakeholders of this venture would be paid in cheese produced by the sheep during the spring and summer months. The success of the venture would always depend on his skills as a veterinarian and master cheese maker. His personal wealth served as a guarantee to sheep owners, since for any sheep lost baca had to compensate with one of his own.

The bacas were liminal creatures. They spent their time, from spring till autumn, up in the alpine pastures, away from the human settlements, seeing few people. Those pastures neighboured with the forests, where the wild animals dwelt, in a space beyond what was known or what could be controlled, a space where the forces of nature acted unencumbered and where other forces, not of this plane, could be active too. Because of the nature of their occupation, bacas could not attend the Sunday Mass or take part in other community events that build a sense of belonging. In the community's imagination, a baca was forever an outsider, living in that outer realm with spirits, bandits and outlaws - those who sought to evade the community's control. And in that outer realm, they were for sure closer to Nature, it was quite probable that they were also closer to God and possibly even his old adversary, the Devil. It was anyone's guess which master they could be serving.

On a more earthly plane, it is no wonder that bacas should be great healers. After all, they had to do a veterinarian's job when up in the bacówka (shepherd's hut) during the season. There was no one else to rely on and everyone would always look up to the baca to solve whatever problems might occur. It makes sense that the baca would have to be able to inspire confidence that he has the resources, be it material or magical to see things through. Bacas were also confirmed healers of men with people coming, even from far away cities, for their advice. They used magic and herbs in their prescriptions, being kind of herbalists and holistic healers of the day, and a lot of times they were successful with their therapies, which only made their fame grow even further. They were highly esteemed and perhaps a little feared by the local populations, as they also could predict the future and in case of some really powerful bacas, bring the dead back to life. 

Tradition

One example of such a baca and magician was a man known as Bulanda (real name: Tomasz Chlipała), who had his pastures deep in the Gorce Mountains where baca Jasiek now tries to revive the communal sheep grazing. Bulanda, who lived mostly in the 19th century (he died in 1912) was well known for his healing and magical powers which included among them an ability to turn water into vodka (BAZIŃSKA 1970:118). People travelled as far as from Berlin and Vienna to seek his advice, when doctors were unable to help them (CEKLARZ 2013:129). His advice when it came to healing people and animals seemed to have worked most of the time, but he gave his advice in all sorts of matters, like life and relationships. Bulanda is still remembered in and around the Gorce Mountains and the stories about him were quite vivid until the middle of the twentieth century, when a Polish ethnographer Sebastian Flizak described this colourful character in an article with a much telling title of "Bulanda - Gorces' last magician".

Here are two examples. There was a woman, who came to him with a request to magically kill her old husband, because she wanted to marry a younger suitor. Bulanda pushed his staff into the ground and said to her: "So you would like to dance with a young guy? Dance here then!" And he forced her with his magic to keep on dancing around this stick of wood until the sun set down, only then releasing her from the spell. Another story, shows his reluctance to act in another questionable matter. When peasant from Rabka came to him asking to influence a result of a land division in his favour, Bulanda who was then already an old man than, refused, sending him away with these words: "Don't be greedy. There is nothing out of it for you or me. A long time ago things like that were done, but now, they are already calling me 'Come! Come!'” at which point he would tap his head with his finger (FLIZAK 1957:194).

The fact that people would talk about coming to Bulanda with such requests points to the fact that such feats were thought to be entirely possible with his powers, and that perhaps some bacas had a weaker "magic ethic" (or had not an angel but a devil helping them) and succumbed to the economic gratifications. Indeed, Bulanda's response to the man trying to get a better share of land seems to hint at a possibility that maybe even Bulanda, in his younger years, when the voices from across the great divide were not yet calling him, perhaps would have been more open to such a request.

Today, baca Jasiek does not feel strong enough to perform the magic during the spring Mixing of the Sheep, but the situation in the Gorce Mountains a little more than a hundred years ago was quite different. It was the baca's power that was clearly greater 

Tradition

than the power of the priest as evidenced by the following story, which ended with a rare impramatur of Bulanda's magical activities. The priest in the village of Niedźwiedź was not strong enough to get rid of the evil spells cast on the parish cow shed and had to outsource that job to Bulanda who completed the task successfully, freed the cow shed from spells and brought the cows back to health. Although the priest was a sworn enemy of all superstition, he gave his approval to Bulanda, saying: "You may perform your practices, for you are not doing anything evil, only good” (FLIZAK 1936:74).

Perhaps the most impressive ability that the bacas possessed that made them especially feared and esteemed at the same time, was bringing the dead back to life. Bulanda animated a dead rabbit that was already hanging stiff on the wall, ready to be prepared for dinner, to amuse his guests (BAZIŃSKA 1970:118). Baca Gruś from Krościenko put the fear in the hearts of the locals who told this story about him:

"He used to be a baca 30 years ago on Obidzka Skatka, and some beggar put a spell on his sheep so that they all died. Gruś said goodbye to all his juhasi telling them that he may not be long for this world. Then he went to the cemetery where, during the night, he dug up a corpse, he was doing some sort of ritual over it (they say he wrestled with it) and then came back to the shepherds' hut. He took out a pole from the enclosure, made a hole in the ground inside the hut with it and poured whey into it, fired up the pole and then inserted it into the hole. There were terrible screams and screeching, but when Grus whistled, all the sheep jumped up from the ground, alive again" (BAZIŃSKA 1970:153).

Such is the nature the pastoral enterprise, that even for the most successful and reputable baca, the outcome of the grazing season would always be uncertain because of the events beyond anyone's control: weather events, accidents, attacks of wild animals like wolves and bears. There was also be dark magic levelled at the animals in his care to worry about. Travelling beggars like that from the Gruś story were magicians to be weary of, but there was also possibility that someone would inadvertently but a spell on sheep just by looking at them. To this day it is better not to look at baca's sheep too intently. With such a wide range or natural and supernatural dangers, a baca would always try to protect himself from these unknown forces with magic of his own. 


\section{Mixing of the Sheep then and now}

Mieszanie owiec - Mixing of the Sheep today, as described earlier, is very different to what it was before, when the baca himself was the most powerful magician around. It usually took place in the baca's village, after all the owners brought their sheep to him before his trek up to the mountains. It used to be quiet affair between the baca and the owners. A serious and solemn occasion, because the new season always brought with it a lot of uncertainty. Is it going to be a good year, or a bad year? Is the baca going to be able to anticipate the weather and set the departure and return days correctly, so that he will not be surprised by a sudden snow? Will the sheep be healthy and will they avoid accidents? What if someone puts a spell on them? Are the sheep themselves going to cooperate and be easy to manage? Is the new big herd made up from all the little herds of individual owners going to act as one big herd and stick together? Sheep that wonder off are a big problem for the shepherds (juhasi), who have to chase after them. They are also likely to fall prey to the wolves and other wild animals, because back in those days also bears and lynxes roamed these mountains. The bacas sought to protect the herd from all these possible dangers through magic performed at the beginning of the season.

Sometimes, a baca would do the Mixing of the Sheep already up on the destination pasture. Here are some examples of the magical protection procedures performed. The following description is from the Gorce Mountains:

"When the baca first arrives on the pasture with his herd he builds the koszar. In the entrance, on the ground he spreads a rosemary consecrated in Calvary ${ }^{1}$, over which the sheep enter into the enclosure. He does that, so that the sheep, which come from different owners and sometimes from distant villages and settlements, would not scatter and become lost in the woods, but stick together. Some bacas bring ants, picked in the woods, in a bag and scatter them around the enclosure before they let the sheep in. Next the baca and the juhasi go to four springs and scoop up water from them three times. This water is boiled with the salt consecrated on St Agatha's Day and the sheep are watered with it. This protects them from witchcraft. Then the koszar is incensed with consecrated herbs and the sign of the cross is made over it with an iron wheel. Finally, the herd is released, is rushed

1 Kalwaria Zebrzydowska is an important place of worship and pilgrimage near the Podhale region. 

Tradition

around the koszar and enclosed in it again. Once all these things are done, even the most powerful sorcerer cannot harm these sheep" (FLIZAK 1936:74-75).

There were also other ways to ensure that mieszanie will be successful in making the sheep stick together. Instead of a rosemary, some bacas used a chain, so that the sheep would stick together like its links. Some made the sheep walk through an old pair of trousers as the trousers are also intended to keep things together and inside. Fire also has an important role in this protective magic:

"Baca makes a sign of a cross on the ground towards the path to the pastures. He makes this cross with charcoal and with the burning herbs. Then, two juhasi held the chain in their left hands so that every sheep would go through the chain. Baca would then let the sheep go so that they would all step through the coals, the cross and the chain" (BAZIŃSKA 1970:170).

Since the beginning of the 19th century there was a curious shift in bacas' traditional magical practices which manifested itself in an effort to boost the effectiveness of their magic by trying to link it with the practices adopted from Catholic Church, as illustrated in the above examples by using the salt blessed on St Agatha's Day and making the sign of the cross with charcoal. The bacas developed their own quasi-religious rituals around their spells where they were the ceremonies' "priests". In the second half of the 20th century a lot of informants were mentioning "mysterious pastoral ceremony" that took place up on the alpine pastures that nobody, except the shepherds could take part in, but as no outsiders were able to take part, they were unable to provide any details (BAZIŃSKA 1970:128).

So all those magical procedures quoted above are just an external part of the mieszanie, visible to the observer, but besides them bacas put protective spells on sheep and performed other magical procedures which were not visible. These, along with the spells, bacas kept to themselves and passed only to their male successors (BAZIŃSKA 1970:116), because being a baca was a hereditary profession. Bulanda did not pass most of his secrets, because he had no son and he judged his son-in-law to be of poor character, and likely to use the powers to harm people (FLIZAK 1957:74). And he did not have enough time to pass them on to his grandson who was only a teenager when Bulanda passed away. His grandson too, became a baca, just not a great magician, and was still working in the Gorce Mountains in the 1960s. 

Tradition

What is conspicuously absent from these old ethnographic descriptions of mieszanie are the priests. They were not there. They were in an adversarial position, warning their parishioners against superstition and witchcraft, admonishing their parishioners not to go turn to the bacas for help that comes from such an uncertain source and recommending prayer instead. A priest from the village of Półrzeczek was a staunch enemy of Bulanda because his parishioners gossiped that there is a devil helping this baca. So when the priest learned that one of his flock sought Bulanda's help for his sheep got sick and lost their milk, he tried his own magic during the Sunday Mass to counter the baca's influence. This left people wondering, when the sheep got back their milk, if it was Bulanda's magic or the priest's prayer that did the trick (CEKLARZ 2013:140).

\section{Crisis of pastoralism - break in tradition}

Sheep pastoralism was a mainstay of highland life and a way to make a decent living as illustrated by an old adage of "kto ma owce, ten ma co chce" meaning "he who owns sheep, can have whatever he wants". It was also at the "core" of the Highland culture and identity. Things began to change in the 20th century with the Second World War and the imposition of the communist system on the entire Central Europe. There was also a great push to educate the masses. The magic of the bacas in the age when the agriculture was being mechanised was already losing its hold over the people's imaginations. The bacas themselves, in the post war period, were drawing their knowledge increasingly from formal sources which led them to evolve away from the baca-magician model. However, the magical tradition was still strong, especially that it also afforded the bacas social and economic advantages (BAZIŃSKA 1970:117). Financially, this has also been a good time for the bacas and in the second half of the 20th century Polish pastoralist have experienced what many bacas fondly recall as pastoralist golden age. The high world wool prices, coupled with an assured market for their cheese output by the state dairy companies, saw the sheep numbers in Poland climb to around 4 million. But this heyday was on the eve of a catastrophe. In the late 1980s the global wool prices fell dramatically (by almost 50\%) and in 1989 the communist system together with it state planned economy collapsed also. The pastoralists were caught in the crossfire of these two global forces and the consequences were devastating. The sheep numbers plummeted to around 300 thousand, with further decline in later years. Poland's accession to the European Union did not reverse this trend (227 thousand in 2015). 

Tradition

These adverse economic circumstances have caused a great decline in the number of people employed in this sector, including the bacas. The old bacas were dying out and a lot of times they had no one to pass their secrets onto as no one was going to be following in their footsteps. It looked like their way of life and their customs were soon all going to be an ethnographic footnote to the region's history. But after three decades without sheep in the mountains it became apparent that this land management system which has been in place for hundreds of years served more than just an economic purpose. Without the sheep's seasonal grazing, the mountain pastures revert to the forest with great losses to biological diversity and a deterioration of landscape with accompanied decline in the region's value as a tourist attraction. There was also the issue of the great cultural loss to the Highland culture.

\section{Revival and reinvention}

Although sheep numbers in the whole of Poland are still falling, the sheep are visibly back in the mountains and, as such events are widely reported on a local level, back in the public perception. This movement to revive mountain pastoralism in southern Poland takes advantage of European Common Agricultural Policy's (CAP) support for livestock management, in what the EU considers "less favoured areas" (LFA). Pastoralism may be in a better position than the straight forward sheep husbandry, because it is able to draw the money from other sources such as agri-environmental programs, like the Sheep Plus program in the province Silesia. A similar program, now starting (2017) for the entire South of Poland, offers the bacas more money for grazing the traditional alpine pastures which have previously been abandoned, thus trying to protect and bring back the biological diversity. Polish mountain pastoralism also has more possible revenue streams from its activity, including the sale of its cheese output, including the iconic oscypek - a rennet based, smoked, hard cheese now protected by the European Protected Designation of Origin (PDO) certificate (Council Regulation /EC/ No 510/2006 2006:96). Oscypek must be hand-made at the bacówka, using the traditional technique and tools, and shaped into its characteristic fusiform shape. The overall picture of profitability is still far from lucrative but "every little bit helps" because to be revived, pastoralism needs a sound economic foundation. There are those that insist its revival is important and must be continued because it is - as baca Kohut of the Transhumance Foundation described it - 

Tradition

a come back to the Highland's culture "core". But this revival will not be successful unless the economic needs of the people involved are met.

However, it is not exclusively about economics, but about the culture, and the cultural aspect of pastoralism is being brought back also. But, as there was this generational gap, a break in cultural transmission, what is being brought back, of necessity, must differ from what was before. It also goes without saying that the world has changed in the last fifty years in all sorts of ways, and pastoralism finds itself within this new world of economics and technology together with the rest of the agriculture. Many customs were abandoned because they did not make sense any more. Like the custom of mirowanie when, during one of the first milkings of the season, the baca and the owners measured their sheep milk yields, which would then become the basis for the settlement in cheese. The reason for this abandonment is simple; no one settles obligations in cheese any more.

Many "new entrants" to the pastoralism business, who did not have direct knowledge of it from their forefathers, have to rely on other sources, like more distant family members, or just older people in the village with the requisite experience. They also augment that knowledge from ethnographic literature. When I first met baca Jasiek (the one who introduced the priest to mieszanie), within minutes of starting the conversation, he asked to be emailed the literature on his village Ochotnica (which was the first village in Poland that was settled according to the "Wallachian law" in 1416) to see if I was able to find anything that he missed. I later found out, he was a long time editor of a local newspaper, and has penned an article published in a book alongside professional ethnographers. When asked about the old customs he would flawlessly recite what is known from the old ethnographic sources, sometimes contrasting it with the modern day and giving his thoughts on the issues (usually trying find the rationale for old customs in their hygienic aspects).

There are still bacas out there, like baca Pawet, who come from a long line of bacas and still do the mieszanie their own way, it is still a quiet affair between the baca and the sheep owners. But these are increasingly rearer and, for obvious reasons, not as much in the public's perception, as there are no tourists or reporters present. It is those more public celebrations, like the one baca Jasiek organises, that are coming to the fore and are thought by the general public as traditional. 


\section{An invented tradition of blessing the sheep "by proxy"}

On the 24th of April 2015 the gardens outside of the shrine in the village of Ludźmierz in the Podhale region were packed with people.

Ludźmierz is probably the most important place of worship for the people of the region. The basilica houses the sculpture of Saint Mary - the patron of Podhale to which many miracles have been attributed. It is also special for another reason, it was visited many times first by Karol Wojtyła who later became the pope John Paul II. During one of the processions a sceptre dropped from her hand and he caught it before it fell to the ground, an event which was interpreted as a divine nomination for his later ascension to papacy. The water from the spring next to the church is also believed, since time immemorial, to have healing properties.

The holy mass took place on the outside altar once erected for one of John Paul II's visits, the miraculous sculpture of Mary looking on at the festivities. The fire fighters and paramedics were on hand in the church parking lot to rescue anyone who might faint on this unusually hot, spring day. There were children with yellow balloons of the Karpaty Łączą Project (aimed at the implementation of the Carpathian Convention, including the promotion of pastoralism and funded by Swiss Contribution), people dressed as Roman soldiers who arrested Christ two thousand years before, Highlanders dressed in their richly embroidered traditional attire, some holding standards of different chapters of their Podhalan Union. The army band of the Podhalan Independent Shooters Brigade was there in their distinct feathered hats. The year 2015 was special, because it was a year of double election. In a few months it was going to be decided who would control the parliament and also who would be the president. Hence, the representatives of local and state branches of the government were there - the voyevoda (top regional government official) of the Małopolska province Jerzy Miller and the incumbent president's, Bronisław Komorowski's wife, Anna. It all points to the fact that this day became an important event in not just the pastoral calendar.

Outside of the church there was a small koszar with no more than two hundred sheep in it. After the mass was finished, and the officials gave their speeches, the priests moved from the altar to it, accompanied by the altar boys carrying a big cross. The event, because of its new significance and photogenic appeal (traditional highland attire and the sheep), was attended by local TV crews and photographers. At one point the photographers filled the koszar in such numbers, to get better shots of sheep with priests, that for a moment it 

Tradition

seemed like there was more of them in the enclosure than the sheep. The consecrating priest in charge blessed the sheep and passed incense over them, while the sheep bleated and moved about, uncomfortable in hot weather and agitated by all the people that have now gathered around them. The priest, assisted by a young man dressed up as juhas, seemed ill at ease with the sheep and went through what was required of him without stepping close to the animals.

This celebration in Ludźmierz has its own name - Święto Bacowskie (or the Day of the Bacas). It is a new tradition which quickly became a very important date in the pastoral calendar, a day when the pastoral season, in a way, is officially opened. It is clearly an invented tradition in the Hobsbawmian sense (HOBSBAWM 2008:10). Bacas from all over the southern Poland and sometimes even from Slovakia come to take part in this initial blessing of the sheep, the blessing which is extended, in priests' prayers, to all the sheep going up to the mountain pastures in Carpathians that year. The bacas also take away from this celebration a singed piece of firewood with which they will start their own first fires of the season and a small bottle of holy water which they then use for their individual mixing of the sheep celebrations back home.

\section{Conclusions}

The role of the bacas as magicians declined in the twentieth century and then disappeared almost completely in the period of pastoral decline caused by the twin events of the fall of communism and the world wool market crash of the late 1980s. Today, there is an effort to bring pastoralism back into the Polish mountains for environmental and cultural reasons and new bacas make their way into this profession. The new entrants to the job lacking the family tradition and knowledge about the different customs associated with the pastoral calendar. This gap in knowledge is filled with ethnographic literature and from surviving old shepherds. By cooperating with their former adversaries, the priests, the new bacas re-create and re-invent tradition. The traditional elements are there, the dates are kept, the fire and water are used, yet, the bacas are no longer in the centre of such celebrations.

This mixture of old and new produces new and surprising outcomes like the invented tradition of the Day of the Baca in Ludźmierz where, by blessing a small herd in the koszar outside the church the priests are blessing, by proxy, all the sheep about to go up to the 

Tradition

alpine pastures. And fire and water, the magical elements which the bacas have always used in their magical practices, now too come pre-blessed by the priests in Ludźmierz during that celebration. It seems that the magical power now rests mostly with the priests, who are now aiding the new bacas in creating a more public way of advertising their revitalisation efforts and drawing to it the public's attention. And it is an important help in this revival because of the priests' influential position in the public life in contemporary Poland.

\section{Bibliography}

BAZIŃSKA, B. (1970): "Wierzenia i Praktyki Magiczne Pasterzy w Tatrach Polskich”. In Włodzimierz Antoniewicz (ed.) Pasterstwo Tatr Polskich i Podhala. Wrocław: Zakład Narodowy im Ossolińskich, pp. 65-229.

CEKLARZ, K. (2013): "Bulanda - Czarownik i Znachor z Gorców w Świetle Badań Etnograficznych z lat 1960-1966.” In Wierchy 16, pp. 127-152.

Council Regulation (EC) No 510/2006. 2006. "Application for Registration in Accordance with Articles 5 and 17(2) 'OSCYPEK." Official Journal of the European Union, 6(510):C 180/94 - C 180/97. Retrieved (http://eur-lex.europa.eu/legalcontent/PL/TXT/?uri=CELEX:52006XC0802(06).

DOBROWOLSKI, K. (1970): "Migracje Wołoskie Na Ziemiach Dawnego Państwa Polskiego." In Włodzimierz Antoniewicz (ed.) Pasterstwo Tatr Polskich i Podhala. Wrocław: Zakład Narodowy im Ossolińskich, pp. 65-229.

FLIZAK, S. (1936): “Z Życia Owczarzy Gorczańskich.” In Wierchy 14, pp. 73-80.

FLIZAK, S. (1957): "Bulanda - Ostatni Czarodziej Gorczański." In Wierchy 26, pp. $192-$ 195.

HOBSBAWM, E. (2008): "Wprowadzenie. Wynajdywanie Tradycji." In Eric Hobsbawm and Terence Ranger (eds.) Tradycja wynaleziona. Kraków: Wydawnictwo Uniwersytetu Jagiellońskiego.

JAWOR, G. (1997): "Współistnienie grup etnicznych na Rusi Czerwonej w XV-XVI wieku na przykładzie stosunku do społeczności wołoskich." In Annales Universitatis Mariae Curie-Skłodowska 52/53(1997/1998), pp. 53-66. Retrieved January 7, 2016 (http://dlibra.umcs.lublin.pl/dlibra/plain-content?id=5710). 
PAWEL SENDYKA

The Bacs and the Priests: How Old Adversaries Came Together to Revive and Reinterpret Tradition

JAWOR, G. (2000): Osady prawa wołoskiego i ich mieszkańcy na Rusi Czerwonej w późnym średniowieczu. Lublin: Wydawnictwo Uniwersytetu Marii Curie-Skłodowskiej.

JAWOR, G. (2014): “W Poszukiwaniu Jedności Gospodarczej i Kulturalnej Obszaru Karpackiego." In Józef Michałek, Edyta Molik, Piotr Kohut, and Maciej Murawski (eds.) Owce i ludzie, informator społeczno-regionalny, pp. 23-27 